\title{
O TEATRO COMO UM SISTEMA DE COMUNICAÇÃO
}

\author{
Marcos Antônio ALVES ${ }^{1}$
}

- RESUMO: A comunicação parece ser um dos objetivos centrais do artista na apresentação de uma peça teatral. Quando acontece essa comunicação, ele e seu público constituem, juntamente com certas características, um sistema comunicativo. Neste trabalho, expomos a noção de um sistema de comunicação proposta por Shannon e Weaver. Procuramos relacionar essa noção com o sistema comunicativo estabelecido na apresentação teatral. Investigamos questões como: quais os componentes necessários para a existência e possibilidade de comunicação entre emissor e receptor?; quando atores têm em mente transmitir uma certa mensagem com um significado determinado e o público a interpreta ou entende de outro modo, pode-se dizer que houve comunicação entre eles?; há a possibilidade de o público comunicar algo ao ator, tornando-se assim o emissor?

- PALAVRAS-CHAVE: Comunicação; informação; teatro; sistema comunicativo.

A comunicação parece ser um dos objetivos centrais na apresentação de uma peça teatral. Na grande maioria dos casos, o artista quer estabelecer uma conexão com seu público. (Entendemos a noção de teatro como a união entre o conjunto de artistas e a platéia. De fato, não conseguimos conceber a idéia de teatro sem nenhuma dessas partes. Ainda que pudéssemos pensar na possibilidade de os artistas serem sua própria platéia, pensar esta sem aquela parece algo absurdo.)

1 Doutorando no programa de Filosofia - UNESP - 17527-900 - Marília - SP. 
Embora seja estranho, é possível pensar que algumas vezes o artista possa não ter intenção de comunicar algo para seu público. Seu único objetivo nesse caso seria fazer uma apresentação. Mas toda e qualquer apresentação tem em si um conteúdo informacional. Dessa forma, uma apresentação que pretenda nada comunicar certamente transmite seu objetivo, qual seja, nada transmitir. Parece impossível escapar da possibilidade de haver comunicação no teatro, dada a própria natureza da apresentação teatral. A própria representação já é uma comunicação. Ainda que pudesse haver peças teatrais sem comunicação, nosso objetivo neste trabalho é falar das peças cujos atores procuram transmitir alguma mensagem.

A comunicação no teatro é realizada pela transmissão de informações e é composta pelo conjunto de atores em um dos extremos e pelo público em outro. Apresentamos aqui o modelo de comunicação proposto por Shannon \& Weaver (1949) e, por meio dele, tentaremos explicar a relação entre artistas e platéia.

A comunicação entre indivíduos se faz presente desde as épocas mais primitivas. Seja por meio de fumaça ou por fibra ótica, o ser humano transmite e busca transmitir informações de um modo cada vez mais rápido, prático e eficiente. O modelo de comunicação que nos interessa é o já referido proposto por Shannon \& Weaver, representado na figura abaixo.

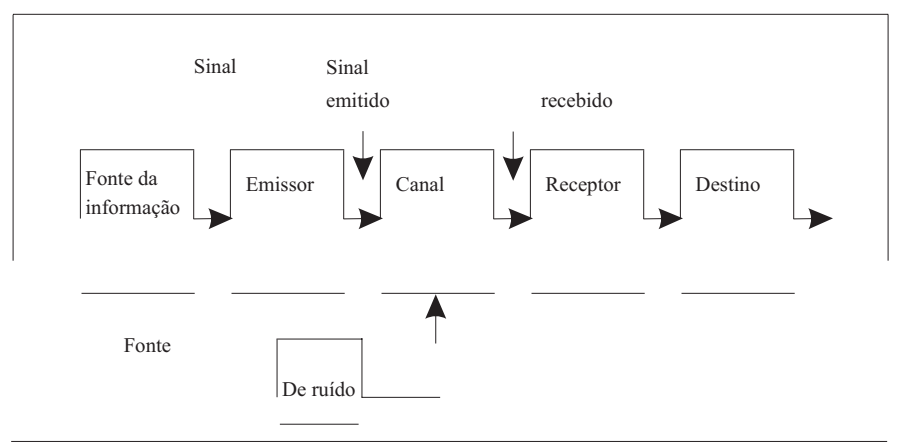

FIGURA 1 - Modelo de comunicação proposto por Shannon \& Weaver.

A comunicação, nesse modelo, principia na fonte, entendida como um conjunto de mensagens (portadores da informação). O emissor seleciona uma mensagem presente na fonte e a converte em um conjunto de 
sinais (Littlejohn, 1985, p.156). O canal é o meio pelo qual são enviados os sinais. O receptor converte os sinais em uma mensagem e o destino é aquele onde se quer que ela chegue.

No caso do teatro, a fonte poderia ser uma obra a ser interpretada. Suponhamos então que se pretende interpretar Hamlet. A obra de Shakespeare é o conjunto de informações das quais algumas delas serão selecionadas pelo emissor. Este poderia ser o diretor da peça, que escolhe as cenas que mais lhe agradam, sem perder a idéia da obra. O emissor são também os atores, iluminadores e todos os outros indivíduos envolvidos na apresentação da peça. O canal é um sistema de ondas sonoras, visuais e outras características que tornam possível a transmissão das informações (considerando que a comunicação, nesse caso, é oral e visual). $\mathrm{O}$ receptor é o público, enquanto um conjunto de indivíduos e o destino poderiam ser suas mentes.

Notemos que, pelo fato de o emissor fazer um recorte das informações presentes na fonte, nem todas elas serão transmitidas. Por outro lado, ao assistir à peça, nem sempre o receptor é capaz de captar toda informação advinda do emissor. Desse modo, existe um recorte do recorte da fonte de informações. A informação captada pelo espectador é uma parcela das informações presentes na fonte, muitas vezes distorcida, dada a possibilidade do receptor interpretar a mensagem de um modo diferente do emissor.

Como dissemos, a comunicação é a troca de informações, que são transmitidas pelas mensagens, que proporcionam a comunicação entre indivíduos. Uma mensagem é um conjunto de símbolos ou signos organizados de acordo com regras. Ela pode ser uma seqüência de letras, sons, luzes ou algo abstrato como o pensamento. A onda elétrica, química, física, produzida pela mensagem que será recebida pelo receptor que a decodificará (transformará novamente em uma mensagem), é denominada sinal. O sinal geralmente é finito, tem curta duração no tempo e depende do canal. A mensagem não precisa do sinal para existir, mas apenas para ser transmitida.

Na comunicação é preciso ainda a existência de um código, segundo o qual será possível a construção de mensagens significativas. Os índios, por exemplo, comunicam-se por meio da fumaça, e a mensagem é transmitida pela seqüência de fumaça. Mas, se ambos, emissor e receptor, não convencionarem ou tiverem noção do significado dessas seqüências (determinadas pelo código), não haverá comunicação. No teatro é importante que público e atores compartilhem a mesma língua e que o significado atribuído por ambos às palavras seja, no mínimo, semelhante. Isso 
porque, do contrário, é muito provável que a informação oral partida do emissor não chegue ao receptor ou chegue de um modo distorcido.

Porém, algumas vezes, mesmo existindo um código convencional entre emissor e receptor, o processo comunicativo pode falhar. Ou seja, a informação originalmente transmitida chega distorcida ao receptor. Isso pode acontecer porque alguns fatores são acrescidos nas mensagens, fatores esses inexistentes na mensagem original produzida pelo emissor. Tais fatores são denominados ruídos. Os ruídos são fontes de perturbação que fazem que a mensagem chegue distorcida ou que nem chegue a seu destino. Um dos grandes objetivos de Shannon \& Weaver era eliminar ao máximo tais ruídos em sistemas de comunicação. Um dos resultados tecnológicos de seu trabalho foi o aperfeiçoamento da comunicação telefônica.

No teatro, o ruído pode ser sons atrapalhando a audição do público, fazendo que a mensagem chegue incompleta ao receptor. Por exemplo, se o ator fala "Eu sou rico", e o receptor ouve apenas "Eu ... rico", não compreende o conteúdo da informação transmitida. Mas o ruído não necessariamente precisa ser barulho. Pode ser, por exemplo, a interpretação errada da mensagem ou sua incompreensão por parte do receptor. Desse modo, se o público distorce a mensagem original advinda do emissor, acrescenta algo nela que não estava originalmente presente. Nesse caso, é evidente que a comunicação não teve sucesso. Para haver comunicação, a mensagem transmitida pelo emissor deve ser compreendida pelo receptor.

Para alguns pesquisadores, o modelo de comunicação de Shannon \& Weaver (1949) não é bom. Segundo Yves (1996), por exemplo, ele representa a comunicação sob a forma de um processo unidirecional em que um emissor tenta deliberadamente influenciar um receptor. Uma tal representação nega toda idéia de circularidade, de interação e de abertura no processo de comunicação.

O que é preciso para haver comunicação entre emissor e receptor? Em primeiro lugar, emissor e receptor devem estar convencionados num mesmo código. Como dissemos há pouco, emissor e receptor devem usar sinais semelhantes, unir e interpretar esses sinais também de modo semelhante. Sendo assim, podemos notar que a comunicação se dá quando realmente emissor e receptor compartilham, além do mesmo código, um significado no mínimo semelhante da mensagem transmitida. Desse modo, se o ator quer transmitir " $X$ " e o público entende "não-X", é claro que não houve comunicação. 
Ainda que algumas vezes o público não entenda a língua a falada em uma peça, pode ocorrer de ele entender a mensagem pelo movimento corporal do artista. Como exemplos podemos citar as óperas e o cinema mudo. Nesses dois tipos de apresentação artística, o canal não é mais um conjunto de ondas sonoras, e sim de ondas visuais. Um sujeito cego nada entenderia da obra, não havendo, portanto, comunicação.

Como vimos, para haver comunicação, é necessária a existência de um código lingüístico semelhante compartilhado pelo emissor e receptor. Além disso, é preciso ainda um canal que transmita as mensagens (podendo existir dois ou mais canais em uma transmissão de informações). É necessário também que o ruído não seja tal que altere significativamente o conteúdo informacional da mensagem transmitida.

Embora a qualidade da informação seja essencial para haver comunicação, Shannon \& Weaver não estão preocupados com esse aspecto. Para eles, o que importa é apenas o aspecto quantitativo das mensagens. Por isso, pesquisadores como Dretske (1981), por exemplo, criticamnos afirmando que eles não conseguem explicar a natureza da informação. Para Shannon \& Weaver, é fundamental, para haver comunicação, que a quantidade de informação que partiu do emissor chegue em medida aproximada ao receptor. Não importa se existe compreensão ou não da mensagem. Desse modo, pode haver comunicação entre máquinas, por exemplo: basta que a quantidade de informação partida da máquina emissora seja captada (sintaticamente) pela máquina receptora.

A simples comunicação sintática parece não satisfazer a explicação da comunicação, em especial, da humana. Não é suficiente analisar a quantidade de informação por meio de cálculos matemáticos para saber se houve comunicação entre ator e platéia. É preciso, além disso, examinar a qualidade da informação: o significado da mensagem presente no receptor deve, no mínimo, ser semelhante ao do emissor.

Por fim, podemos nos perguntar se há a possibilidade de o público comunicar algo ao ator, tornando-se assim fonte da informação. É claro que há essa possibilidade e o artista deve estar preparado para isso. O público se comunica com o ator por meio de risos, aplausos, vaias, expressões corporais etc. Esse é o feedback do público, sua resposta à ação do emissor. A análise da comunicação dá-se do mesmo modo de quando a fonte era o artista e não o espectador.

De fato, um artista inteligente precisa moldar-se de acordo com seu público, o que não significa estar determinado por ele. É claro que não é possível, em uma ópera, por exemplo, que o ator molde-se de acordo com o desejo do público. A alteração e criação da peça por causa da resposta 
do público é muito evidente em certas comédias. Embora essa relação com o público possa ser salutar, o ator deve ter cuidado para não ser manipulado pelo espectador. $\mathrm{O}$ ator deve ser autônomo, sem desmerecer por completo a exigências, potencialidades e capacidades da platéia. O ideal é que ele encontre um meio termo: afetar e ser afetado pelo público. Com isso, haverá um envolvimento com o público e uma troca de informações constante, cujo fim último é a aprendizagem, a diversão e o progresso humano.

ALVES, M. A. The theater as a communication system. Trans/Form/Ação (São Paulo), v.24, p.85-90, 2001.

- ABSTRACT: Communication seems to be one of the artist's central objectives in the performance of a theatrical play. When that communication takes place, the artist and his public constitute a communicative system. In this work, the notion of communication system proposed by Shannon \& Weaver is presented. This notion is related to the communicative system established in theatrical presentation. Subjects such as the following ones are investigated: which are the necessary components for the existence of communication between emitter and receiver?; when actors have in mind to transmit a certain message with a certain meaning and the audience interprets or understands this message in another way, can it be said that there was communication between them?; can the public communicate something to the actor, becoming thus the emitter?

- KEYWORDS: Communication; information; theater; communicative system.

\section{Referências bibliográficas}

DRETSKE, F. Knowledge and the flow of information. Oxford: Basil Blackwell, 1981.

EDWARDS, E. Introdução à teoria da informação. São Paulo: Cultrix, 1971.

LITTLEJOHN, J. Teoria da comunicação. São Paulo, 1985.

REZA, F. An introduction to information theory. New York: McGraw-Hill, 1961.

SHANNON, C., WEAVER, W. The mathematical theory of communication. Chicago: University of Illinois Press, 1949.

YVES, F. A ciência da informação. Brasília: Briquet de Lemos livros, 1996. 